\title{
A DIMENSÃO GEOPOLÍTICA DA CRISE BRASILEIRA: UMA PERSPECTIVA DESDE OS GRUPOS SOCIAIS EM SITUAÇÃO DE SUBALTERNIZAÇÃO ${ }^{1}$
}

\author{
Carlos Walter Porto-Gonçalves ${ }^{2}$ \\ Universidade Federal Fluminense
}

\begin{abstract}
Resumo: Analisa-se o novo contexto geopolítico que se abre com o deslocamento do centro dinâmico do capitalismo em direção à Ásia e ao Pacífico e as bifurcações políticas possíveis. Essa análise se dá através da atual crise política latino-americana, particularmente a partir da crise brasileira. Teórica e conceitualmente, o artigo se coloca na perspectiva de grupos/classes sociais em situação de subalternização quase sempre ignorados nas análises geopolíticas que tendem a sobrevalorizar as escalas políticas nacional e global e, deste modo, a desqualificar a escala local. Sustenta-se que as escalas geográficas não são neutras politicamente.
\end{abstract}

Palavras-chave: Tensões Territoriais; Integração Latino-Americana; A Geopolítica na Perspectiva de Grupos/Classes Sociais em Situação de Subalternização.

\section{THE GEOPOLITICAL DIMENSION OF BRAZIL'S CRISIS: AN ANALYSIS FROM THE STANDPOINT OF SUBALTERN SOCIAL GROUPS}

Abstract: This paper analyzes the new geopolitical setting created by capitalism's shifting dynamic center toward Asia and the Pacific and its potential political outcomes. This analysis turns to the current political crisis in Latin America, and in particular in Brazil. At a conceptual and theoretical level, the paper takes into account the point of view of subaltern social groups and classes, often ignored in geopolitical analyses that tend to over-emphasize the global and national political scales and, in so doing, to downplay the local scale. It is claimed that geographical scales are not neutral from a political perspective.

Keywords: Territorial Conflicts; Latin-American Integration; Geopolitics from the Point of View of Subaltern Groups and Classes

\footnotetext{
${ }^{1}$ Ensaio produzido como parte do Pós-doutorado no Programa de Pós-Graduação Interdisciplinar em Ciências Humanas (PPGICH) do Centro de Filosofia e Ciências Humanas da Universidade Federal de Santa Catarina (UFSC), sob a supervisão do PhD. Luiz Fernando Scheibe.

${ }^{2}$ Professor adjunto da Universidade Federal Fluminense. Contato: cwpg@uol.com.br.
} 


\section{Alguns pressupostos teórico-políticos à guisa de introdução}

Há uma dimensão geopolítica a ser devidamente considerada para compreender as transformações que estão em curso na América Latina, sobretudo pelos desafios que se colocam para os grupos/classes sociais em situação de subalternização. Neste artigo, essa problemática será analisada a partir do significado da crise brasileira para os destinos da América Latina e de seus povos, sobretudo. O Brasil é o $4^{\circ}$ país do mundo em extensão territorial contínua, o $5^{\circ}$ em termos demográficos e o $8^{\circ} \mathrm{PIB}$ do mundo em 2015 (era o $5^{\circ}$ em 2011). No continente americano, o Brasil é o $2^{\circ}$ maior país em extensão territorial contínua, atrás do Canadá; e o terceiro se considerarmos a área descontínua, pois os EUA incluem o Alasca e o Havaí; o $2^{\circ} \mathrm{em}$ termos demográficos e o $2^{\circ}$ PIB. Esses dados implicam que o Brasil tem um peso próprio no cenário internacional, o que nem sempre é devidamente considerado mesmo nos debates acadêmicos, exceto em algumas áreas de estudo específicas. $\mathrm{Ou}$ seja, a importância geopolítica do país não ocupa o lugar que merece na sua agenda política e mesmo acadêmica. Essa desconsideração do significado geopolítico do país se expressa, entre outras coisas, pelo relativo desprezo que setores políticos e intelectuais devotam à América Latina e a maior importância que os EUA ocupam no debate das nossas relações internacionais. Tudo indica que esse cenário esteja com os dias contados em função da reconfiguração geográfica e política que está em curso no sistema mundo, que impõe definitivamente essa consideração às elites políticas e intelectuais, o que nos obriga a considerar mais seriamente nossas relações com a América Latina e o Caribe. Afinal, está em curso um deslocamento do centro geoeconômico do mundo em direção ao Oceano Pacífico, o que implica importantes consequências haja vista que, desde 1492, o sistema mundo se organizara em torno do Oceano Atlântico Norte. O Brasil é um país do Atlântico e sem saída para o Pacífico, o que por si só nos impõe maior aproximação política, social e cultural com nossos vizinhos pelas novas implicações geopolíticas que se colocam. Isso implica levar em consideração toda a dimensão geográfica envolvida nessa questão, ao invés de continuarmos a ver o espaço olvidando da geografia, como costuma acontecer nas análises das ciências sociais, inclusive na ciência política, nas relações internacionais, na economia e mesmo na geopolítica. Afinal, o espaço geográfico tem espessura e não é somente uma base espacial. Entre o Brasil e a Ásia não há somente distâncias a serem superadas, mas múltiplas geografias a serem consideradas, em que a territorialização de capitais sedentos de obter lucros nos novos mercados necessariamente se verão diante de grupos/classes sociais que nessas áreas estão territorializados, muitos em r-existência secular. Consideremos, ainda, que partilhamos como latino-americanos das vicissitudes que derivam da posição periférica no sistema mundo capitalista moderno-colonial, ainda que o Brasil disponhade condições territoriais - riquezas naturais, demográficas e econômicas - que impõem ao país responsabilidades diferenciadas, a bem dizer, maiores responsabilidades. Isso implica levar devidamente em consideração os 
movimentos geopolíticos dos EUA, não só pelo papel histórico que esse país tem nos destinos da América Latina ${ }^{3}$, mas também porque sendo os EUA uma "grande ilha" entre os oceanos Atlântico e Pacífico implica que continuará tendo um protagonismo no cenário geopolítico mundial mesmo com o deslocamento para o Pacífico, não fora a potência militar e econômica que indiscutivelmente é. Consideremos, ainda, neste xadrez geopolítico que se abre, a relevância que vem assumindo na região (1) a China, que já se constitui no país de maior investimento e principal parceiro comercial em toda a América, mas também (2) a emergência à cena política de grupos/classes sociais em situação de subalternização, como os povos indígenas, camponeses, quilombolas e as populações das periferias urbanas onde as mulheres vêm se destacando. Registre-se que até mesmo o poder de designar a região/o continente entrou em debate nos últimos anos, com os povos/nacionalidades indígenas propondo designar o continente como Abya Yala (PORTO-GONÇALVES, 2008) e, ainda, o fato de as periferias urbanas e suas populações virem sendo definidas como novo alvo das estratégias geopolíticas dos Estados, conforme diversos autores vêm chamando a atenção, entre eles Mike Davis (DAVIS, 2006) e Raul Zibechi (ZIBECHI, 2016).

Nesse artigo procuramos trazer ao debate as implicações que esse novo quadro geopolítico coloca para os grupos/classes sociais em situação de subalternização, o que quase sempre fica de fora das análises geopolíticas. Afinal, a análise geopolítica se coloca, em geral, numa escala geográfica e política que ignora a escala local ou, quando a considera, o faz na perspectiva da dominação e controle por parte dos grupos/classes sociais que operam a partir das escalas nacional e supranacional.

Segundo G. Arrighi (ARRIGHI, 1994), o ordenamento do sistema geopolítico mundial está fundado em dois pilares, a saber: o pilar capitalista, que dá sustentação à acumulação de capital (D-D') e o pilar territorialista (T-T'), que, desde o Tratado de Westfallia (1648), se funda no princípio de soberania territorial do Estado que dá sustentação ao controle do espaço (de seus recursos e de suas gentes). Para os

\footnotetext{
3 Não se pense que se trata de teoria conspiratória, como se costuma dizer. Há fatos históricos suficientemente graves que justificam a permanente preocupação com uma possível intervenção estadunidense. O México, por exemplo, entre 1845-1848 teve seu território amputado de toda a área do Texas à Califórnia passando pelo Arizona e Novo México. A Colômbia viu seu território ser amputado por pressão dos EUA, dando origem a um canal e a um novo país, o Panamá. O bloqueio de mais de 50 anos a Cuba dá mostras do modus operandi geopolítico imperialista dos EUA. Para que se tenha uma ideia do significado dessa ação propriamente territorial, basta lembrar que os EUA promoveram uma reforma agrária em Porto Rico desapropriando até mesmo a empresa estadunidense Unit FruitCo, por entender que o significado geopolítico daquele país do Caribe era mais importante que os interesses de uma determinada empresa cuja presença naquele país se fazia através de um latifúndio e em aliança com os latifundiários locais, o que ensejava continuada tensão social e consequente instabilidade política. Registre-se que os EUA fizeram o mesmo no Japão no pós-guerra, sobretudo depois que a luz vermelha se acendeu com a Revolução Chinesa, em 1949.
} 
grupos/classes sociais em situação de subalternização, a dificuldade já se apresenta pelo fato dessas duas lógicas geopolíticas se conformarem justamente como lógicas de controle e dominação sobre eles e suas territorialidades/territórios. Perry Anderson (1976), entre outros, já assinalara que as Monarquias Centralizadas e os Estados Absolutistas conformaram o Estado Territorial consagrado no Tratado de Vestfália. Segundo ele, esses Estados se forjaram como "Senhorios Centralizados" contra as revoltas camponesas que se generalizavam na Europa e às quais a forma geográfica de organização do poder fragmentada territorialmente nos feudos já não conseguia mais dar conta do controle social. Assim, a centralização do poder conformando uma nova escala de poder no Estado territorial moderno se constituiu, na verdade, numa forma moderna de controle contra os grupos/classes sociais que, desse novo modo, passaram a ser subalternizados. Desde então, tudo que é local é desqualificado, com a cultura local passando a ser vista como folclore e a língua como dialeto. Destaque-se, como o fizeram o geógrafo occitano-francês Robert Lafont (1971) e o sociólogo Pablo Gonzalez Casanova (2006), que o colonialismo interno conformou cada Estado territorial, colonialidade essa que também conformou a ordem geopolítica mundial que, assim, está fundada em princípios coloniais em suas múltiplas escalas e não só na escala intercontinental. Desse modo, temos uma ordem geopolítica que, em suas diversas escalas, se vê atravessada pelo colonialismo, ou melhor, pela colonialidade do poder, para usar a expressão sugerida por Anibal Quijano (2000), e pela colonialidade do saber, conforme Edgardo Lander (2000), que se sustenta na dominação de classe, étnico-racial, patriarcal e da natureza. Foram, sobretudo, os varões, burgueses e gestores, brancos e criollos que protagonizaram a instituição dessa ordem mundial.

A distinção entre Burgueses e Gestores nos parece essencial para caracterizar lugares/posições de classe que nas relações sociais e de poder operam, seja com a lógica privada do capital (a burguesia em sentido clássico), seja com a lógica espacial/territorial (os gestores). Considere-se que tanto os burgueses quanto os gestores dependem do excedente social, que numa ordem geopolítica mundial capitalista se configura como mais-valia, sob suas diversas formas: lucro, juros, ganho comercial, renda da terra (do solo e do subsolo) e impostos. Observemos que o Estado, através dos gestores territoriais, tem um papel fundamental na articulação com o capital, para lhe garantir a propriedade, a segurança de investimentos, a apropriação e distribuição da renda da terra (água, solo, subsolo, diversidade biológica) ${ }^{4}$, na circulação (emissão de moeda) e transporte. A distinção entre Burgueses e Gestores talvez nos ajude a entender melhor a natureza do Capitalismo histórico que na geopolítica atual se conforma na aliança contraditória em disputa pela hegemonia entre a China, onde temos o Capitalismo de Estado Monopolista, e

\footnotetext{
${ }^{4} \mathrm{E}$, cada vez mais, avança sobre outras qualidades da terra, em sentido amplo, como vem fazendo com a financeirização/rentabilização do carbono, e instrumentaliza a crise ambiental reduzindo a complexidade climática a uma variável: os gases de efeito estufa.
} 
os EUA, onde temos o Capitalismo Monopolista de Estado. A ordem dos termos Monopólio e Estado nos dá conta da hegemonia da Burguesia ou dos Gestores.

Afinal, por princípio, o Estado é o proprietário eminente e é o ente que concede a propriedade efetiva, embora saibamos que essa ordem de que o Estado é o instituto emana de processos e grupos/classes sociais que o instituíram enquanto ordem dos proprietários, ainda que se tenha que absorver as contestações que lhes são postas pelos grupos/classes sociais que resistem às suas imposições, segundo as circunstâncias das conjunturas políticas geograficamente desiguais. Não olvidemos o caráter contraditório da propriedade privada por toda implicação social e política, pois, a propriedade privada priva e ao privar muitos de propriedade cria condições objetivas de conflitos. O Estado, bem o sabemos, depende dos impostos que, como o próprio nome indica, deriva da imposição, que bem pode dar-se pela persuasão como pela força, o que põe no centro do debate a questão da hegemonia (Gramsci). O Estado, ao estabelecer a propriedade privada, sempre define um monopólio e, no caso da terra, garante ao proprietário uma renda absoluta com o controle do acesso a um bem natural e a apropriação do excedente social. O Estado, mesmo na tradição liberal como proprietário eminente, ainda que dê suporte à propriedade privada (aos proprietários privados) deve agir em nome do interesse geral, do bem comum, o que exige que a hegemonia esteja bem concertada, até porque muitas são as contradições que atravessam as sociedades, não só as contradições de grupos/classes sociais como as que derivam das tensões de gênero e étnico-raciais, haja vista o patriarcalismo e o racismo que conformam o sistema mundo capitalista moderno-colonial - o que nem sempre é devidamente levado em conta nas análises geopolíticas.

Uma das principais características dos países/sociedades em posição periférica no sistema mundo capitalista moderno-colonialé que o centro geográfico dinâmico da acumulação de capital se situa fora de suas fronteiras territoriais. Desse modo, a inserção desses países/sociedades no sistema mundo capitalista moderno-colonial se dá de modo subordinado/dependente das demandas vindas do centro e, quase sempre, para atender a grande demanda de matéria-prima e energia. Como a transformação da matéria bruta em matéria-prima não é natural, o atendimento dessas demandas implica violência para isolar algum elemento do contexto territorial, seja de suas múltiplas relações biocenóticas nas diversas biotas, seja dos diversos contextos socioculturais em suas múltiplas territorialidades/temporalidades. Aqui, ganha todo sentido a tese de que o Estado deve ter a prerrogativa do monopólio da violência legítima (Max Weber). Todavia, a legitimidade da violência implica o exercício da hegemonia não só pela violência, mas, sobretudo, pela persuasão (Gramsci). A exportação de matérias-primas pelos países/sociedades periféricas tem implicado que o Estado exerça papel relevante na destinação das suas riquezas aos grupos e classes sociais e, nesses países/sociedades, vem exercendo o monopólio da violência admitindo o monopólio não simplesmente da propriedade, mas da grande propriedade, separando o acesso do subsolo do acesso ao solo, o que agrava seriamente a situação dos povos indígenas, de camponeses e 
quilombolas, na medida em que para acessar o subsolo e explorar minérios, gás e petróleo suas terras na superfície são afetadas.

A superexploração do trabalho/natureza é o modus operandi das relações sociais e de poder nos países/sociedades periféricos/as (Marini),onde a acumulação primitiva e a mais-valia absoluta são as faces antagônicas necessárias da acumulação civilizada e da mais-valia relativa que operam nos países/sociedades do centro.

Enfim, o Estado participa ativamentedo jogo da produção/apropriação do excedente social que, sabemos, é fruto da correlação de forças ou,caso se prefira, das lutas sociais e de classes. Assim, o Estado como órgão que se vê (e quer ser visto) separado da sociedade, participa da constituição da ordem geopolítica mesmo quando opera com um sentido redistributivo, como vêm fazendo os governos que se consideram pós-neoliberais. Atentemos, pois, que mesmo operando com um sentido redistributivo da renda, que é parte da apropriação da mais-valia, o Estado participa das relações de poder de extração, apropriação/distribuição do excedente social e, portanto, das assimetrias que atravessam as relações sociais e de poder. Eis o dilema em que se encontram muitos governos que se apresentam como protagonistas de outra ordem social e política e que, ao estimularem a exportação de commoditties para se apropriarem da renda e redistribuí-la,mais aprofundam a ordem que acreditam combater. Afinal, a renda é uma fração da mais-valia.

Sublinhemos, para garantir o rigor analítico necessário, que a "racionalidade dos gestores", que se legitima em nome do interesse geral,ao invocar o interesse nacional acaba, com a expressão nacional, por esconder que dentro do território de seus países/sociedadeshá conflitos de gênero, étnico-raciais e sociais relevantes, uma colonialidade própria que constitui o que Pablo Gonzalez Casanova designou "colonialismo interno".

As análises geopolíticas sobrevalorizaram os dois principais protagonistas do sistema mundo capitalista moderno-colonial - os Gestores e o Capital (sobretudo os Grandes Monopólios Capitalistas Transnacionais) - e, com isso, (1) sobrevalorizaram as escalas nacional e global e (2) invisibilizaram os grupos/classes sociais que operam desde a escala local, onde se dão as resistências/rebeldias/revoltas e se forjam outros possíveis horizontes de sentido emancipatórios. Nas análises geopolíticas, o espaço (e seus recursos) é mais importante que a sociedade em suas relações contraditórias de poder e, assim, prepondera a perspectiva gestorial, que, desse modo, se mostra funcional aos interesses capitalistas, pois a dinâmica espacial dilui a compreensão das contradições sociais e de poder. Nessas análises, é o controle do espaço e dos recursos sendo disputados pelos gestores estatais contra ou em aliança com o capital que, desse modo, invisibilizam/inviabilizam os grupos/classes sociais em situação de subalternização e suas alternativas de gestão/controle territoriais. Talvez aqui residao grande imbróglio teórico-político entre a Gestão (e os Gestores) e a questão da autonomia e da autogestão dos grupos e classes sociais que lutam para preservar 
ou conquistar o controle/gestão-autogestão sobre os meios de vida que, na sua essência, questionam as relações sociais e de poder heterônomas que constituem em suas diversas escalas o sistema mundo capitalista moderno-colonial que nos habita.

Há uma tradição nas lutas revolucionárias em que essas questões vieram à luz e interpelaram o debate teórico-político, como na Comuna de Paris, em 1871; nos Conselhos, na Hungria e na Alemanha; nos ejidos na Revolução Mexicana de 1910; nos soviets na Rússia e, mais recentemente, vêm sendo sugeridas nas lutas em curso na América Latina, como nas Juntas de Bom Governo e nos Caracoles zapatistas, nas Terras Comunitárias de Origem na Bolívia, no debate em torno da Plurinacionalidade que os povos/etnias/nacionalidades indígenas - campesíndios (Armando Bartra) e/ou indigenatos (Darcy Ribeiro) - conseguiram inscrever nas Cartas Magnas do Equador e da Bolívia, sendo que na Bolívia o Estado Plurinacional se proclamou como Estado Plurinacional Comunitário. O mesmo também pode ver visto no caso da luta protagonizada pelos zapatistas mexicanos pelo reconhecimento dos direitos coletivos e comunitários dos povos/nacionalidades indígenas através dos Acordos de San Andres; no Brasil, na invenção dos seringueiros das "reservas extrativistas"; ou, na Colômbia, nas lutas camponesas pelas Reservas Campesinas.

Como se vê, há novos horizontes teórico-políticos sendo colocados desde outras perspectivas, desde outros lugares de enunciação no sentido pleno do conceito de lugar, inclusive em sua geograficidade (PORTO-GONÇALVES, 2003), e não só no sentido discursivo e/ou social com que se invoca o lugar de enunciação ${ }^{5}$. Afinal, autonomia, em grego, indica dar-se as próprias (auto) regras (nomos) e, no caso da autogestão, é importante notar que o próprio termo explicita a contradição entre o caráter de se dar as próprias regras (auto) diretamente com a ideia de gestão tão cara aos gestores 6 .

\footnotetext{
${ }^{5}$ A ideia de lugar de enunciação tende, nas ciências sociais, a sobrevalorizar o lugar na estrutura social e de poder e a olvidar a situação/posição geográfica do lugar. Afinal, vivemos num sistema mundo capitalista moderno-colonial que se estrutura através de relações sociais e de poder configuradas de modo centroperiférico em distintas escalas, que vão da escala local à regional, à nacional, à regional-continental e à escala global/mundial, não necessariamente de modo sucessivo e ascensional. A expressão centro-periferia não deve ser vista somente como uma metáfora espacial que indica uma assimetria nas relações sociais e de poder, mas também em sua geograficidade, em que além dessa dimensão entram as dimensões simbólicas e materiais que soem caminhar mais juntas do que admitem explicitamente as análises geopolíticas. Afinal, a própria designação de América e de África, por exemplo, já trazem consigo uma posição inferiorizada/desqualificada dessas regiões/continentes como se pode facilmente verificar com o que pensavam sobre elas "grandes pensadores" como Kant e Hegel.

${ }^{6}$ Assim, o debate parece ser menos entre ideologias, como comunistas e anarquistas o fazem, e mais como luta de classes, no caso entre Gestores e os grupos/classes sociais em situação de subalternização, em suas lutas emancipatórias em busca de autonomia.
} 


\section{Um novo quadro geopolítico pós-queda do Muro de Berlim}

Desde a queda do muro de Berlim, em 1989, que uma nova geografia política vem se desenhando. Os EUA bem que buscaram afirmar uma perspectiva unilateralista, que já no início dos anos 1990 se mostrou problemática com a primeira invasão que protagonizaram contra o Iraque (1991). Ao longo da década de 1990 e, com mais clareza ainda, no início dos anos 2000, os efeitos da aliança antissoviética entre os EUAe a China (1971-1972) se mostrariam com a China reassumindo sua condição de protagonista na geopolítica mundial. Talvez não estivesse no horizonte dos estrategistas estadunidenses o grande salto no desenvolvimento das forças produtivas dado pela China, em grande parte tornado possível com a aproximação entre os dois Estados desde a famosa visita de Richard Nixon à China, em 1972 (Figura 1). Na verdade, não estava no horizonte dos estrategistas estadunidenses o que os gestores do Partido Comunista chinês seriam capazes de fazer, tanto por sua capacidade gestorial de planejamento territorial interno, como nas suas estratégias geopolíticas regionais/continentais e globais.

São grandes os efeitos desse novo quadro geopolítico não só na geografia do continente americano, mas de todo o mundo. Pela primeira vez desde 1492, o Atlântico Norte passaria a deixar de ser o centro dinâmico da geografia econômica mundial, o que por si só indica novas condições de possibilidades geopolíticas. Os portos estadunidenses do Pacífico, por exemplo, já superam o volume de negócios dos portos do Atlântico. As grandes corporações estadunidenses e europeias buscam novas oportunidades trazidas pelos "negócios da China", trasladando suas plantas industriais para esse país. 


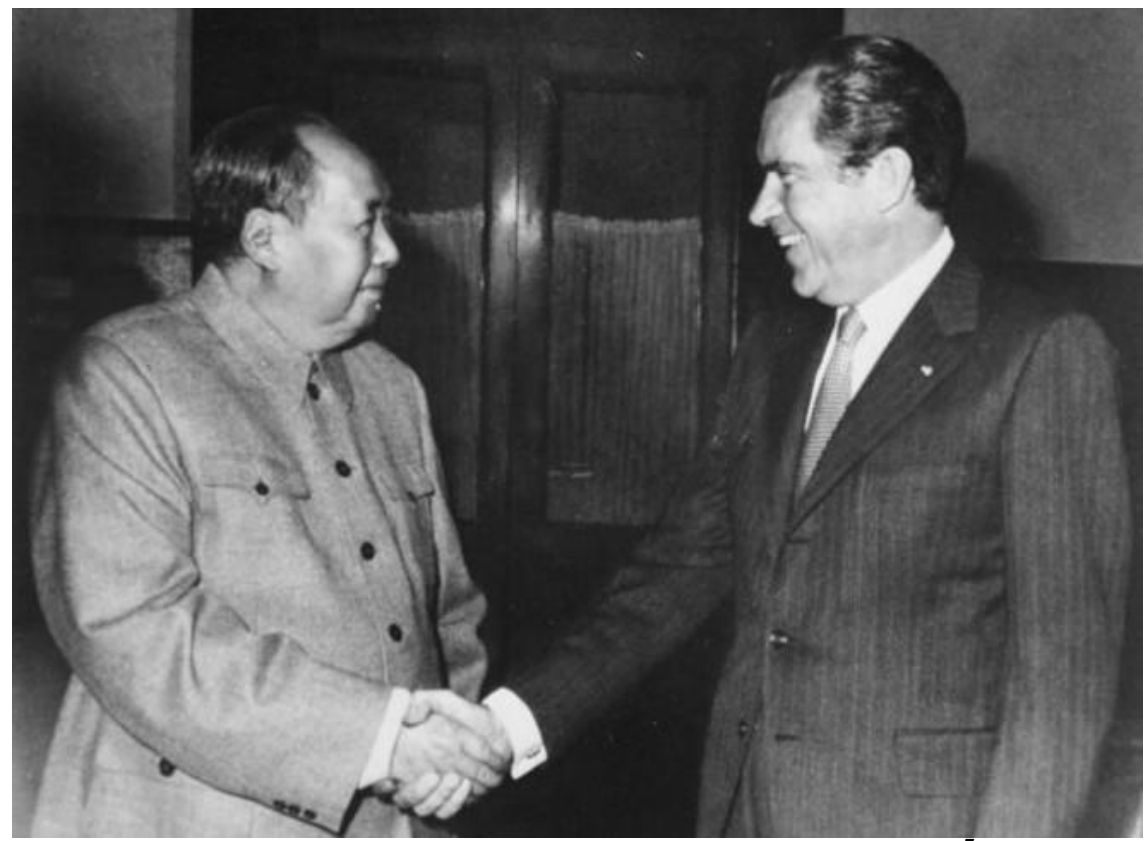

Figura 1: Richard Nixon apertando a mão de Mao TseTung7

Tudo indica que também não estava no horizonte dos estrategistas estadunidenses a resistência ativa (r-existência) das populações das periferias urbanas e dos camponeses, indígenas e quilombolas/pallenqueros da América Latina contra as políticas neoliberais que aumentaram no continente a partir do Consenso de Washington, como se viu desde o Caracazo de 27 de fevereiro de 1989, as grandes marchas pela Vida, pela Dignidade e pelo Território da Bolívia e do Equador de 1990, o Levante Zapatista de $1^{\circ}$ de janeiro de 1994, a Guerra da Água em Cochabamba em 2000, a Guerra do Gás em 2003, ambas na Bolívia, entre outras manifestações que contribuíram para deslegitimar aquelas políticas.

Há uma interessante coincidência a ser devidamente considerada entre a queda do muro de Berlim e a derrocada da URSS, em 1989-1990, e o protagonismo dos movimentos sociais na América Latina em que novas/antigas formações étnicas e sociais emergem na cena política, como os camponeses, os povos indígenas e as populações negras (que também predominam entre as populações das periferias urbanas) - que, diga-se de passagem, aumentaram de modo significativo com a expansão/invasão ${ }^{8}$ do agribusiness patrocinado pelos governos neoliberais, que, inclusive, fizeram regredir conquistas de governos nacionalistas populares,os quais

\footnotetext{
${ }^{7}$ Fonte: https://www.google.com.br/. Nixon apertando a mão de Mao TseTung.

8 Considerar a expressão "expansão/invasão" implica admitir a contradição, pois "expansão" é a perspectiva do capital que avança e "invasão" indica que a "expansão" não se dá sobre áreas vazias, mas sobre áreas já ocupadas, portanto, invasão.
} 
haviam feito reformas agrárias nos anos 1960/1970. No caso das populações urbanas que se mobilizam, cabe não só registrar o que o ativista sindical argentino Vitor de Genaro declarara ao dizer que "nossa nova fábrica é o bairro", como também o protagonismo das mulheres nas periferias urbanas, indicando que o proletariado não pode prescindir daquelas que cuidam da prole para superar as condições de opressão/exploração ${ }^{9}$.

Os anos 1990 foram de grande mobilização de povos/etnias/nacionalidades e das populações das periferias urbanas, mesmo num momento de crise que abalou as esquerdas tradicionais, o que talvez nos ajude a entender a emergência de identidades que até então estavam fora do léxico das práticas políticas tradicionais, como bem é o caso das identidades indígenas e das populações negras, em seus pallenques e quilombos reivindicando seus territórios/suas territorialidades e não mais simplesmente terra (PORTO-GONÇALVES, 2001). São esses movimentos de r-existência (PORTO-GONÇALVES, 2001) que tornarão possíveis outros governos que passam a assumir a gestão do Estado, posto em crise não só pelas contradições internas próprias do modelo de regulação neoliberal, mas pela ação/manifestação desses movimentos, sobretudo depois da eleição e posse de Hugo Chávez Frías (1988-1989). E, com esses novos governos, a questão da gestão/dos gestores se mostrará mais claramente pelas condições de possibilidade que se apresentam com a presença protagonista da China e com o deslocamento do polo geográfico do capital industrial para a Ásia, sob a hegemonia do capital financeiro. Uma espécie de segunda Guerra Fria ou Quarta Guerra Mundial ${ }^{10}$ se configura em que os gestores estatais de alguns países latino-americanos passarão a ter um papel de destaque, particularmente no Brasil, na Venezuela e no Equador, que ensejarão o que alguns autores chamaram de "giro à esquerda" (J. L. Fiori), no qual se destacam ainda a Bolívia, o Uruguai, o Paraguai (até o golpe de Estado contra F. Lugo), a Nicarágua e El Salvador.

\section{Uma perspectiva geopolítica vista a partir da atual crise brasileira}

No atual momento de crise que vive a América Latina/Abya Yala, o Brasil oferece uma perspectiva importante por todo o significado que o Estado e os capitais brasileiros têm no atual contexto de reconfiguração geográfica do capitalismo

\footnotetext{
${ }^{9}$ Não deixemos escapar que cuidar da prole indica, na sociedade capitalista, cuidar da reprodução da força de trabalho assalariada, enfim, do proletariado. Assim, a luta da mulher, como tal, se mostra indissociável das lutas de classes e não pode ser reduzida a essas, como certo marxismo quer fazer crer. Afinal, o trabalho não-pago da mulher em casa é parte da taxa de exploração da mais-valia na fábrica. A classe proletária não se restringe ao lugar da produção, a fábrica, mas se estende ao lugar da reprodução, a casa.

${ }^{10}$ Para os zapatistas, a Guerra Fria foi a Terceira Guerra Mundial e, depois da queda do muro de Berlin, segundo eles, teríamos entrado na Quarta Guerra Mundial.
} 
mundial, sobretudo para os destinos da sub-região sul-americana, particularmente para os destinos dos grupos/classes sociais em situação de subalternização.

Hoje, de modo mais explícito que em qualquer outra época histórica, os grupos/classes sociais hegemônicos na estrutura de poder brasileira vêm manifestando sua vinculação geopoliticamente subordinada/dependente com relação aos EUA, como se vê por intelectuais que se expressam amplamente na grande mídia e recentemente pode ser vista nas grandes manifestações de rua convocadas contra a Presidenta Dilma Rousseff e o Partido dos Trabalhadores.

A recente nomeação do Senador José Serra, do PSDB, para Ministério das Relações Exteriores, feita pelas forças políticas que afastaram a Presidenta Dilma Rousseff do PT é, nesse sentido, emblemática. Afinal, o Sr. José Serra e o sociólogo FHC foram protagonistas, nos anos 1970, de um debate interno à teoria de dependência, quando se colocaram contra a vertente marxista representada por Ruy Mauro Marini, Theotônio dos Santos e Vânia Bambirra (OURIQUES, 2015). Portanto, a nomeação de José Serra, com o apoio de FHC, nos indica que não estamos diante de um debate meramente conjuntural, como alguns podem pensar, mas de distintas linhas políticas do Estado brasileiro no cenário geopolítico regional e mundial. Reforça essa tese o fato de, recentemente, tanto à direita como à esquerda do espectro ideológico, a figura de Simón Bolívar vir sendo invocada, o que não deixa de ser uma novidade, pelo menos no debate interno à sociedade brasileira, onde, ao contrário dos demais países latino-americanos, esse recorte bolivariano não tem maior tradição. O fato de se invocar o "bolivarianismo" revela as novas condições de possibilidade que os anos 1990 colocam para a afirmação dos gestores estatais nacionalistas latino-americanos, sobretudo depois da ascensão da China à condição de destaque no cenário geopolítico mundial. Sabemos que a figura de Simon Bolívar goza de forte tradição na Venezuela ${ }^{11}$ por seu antiamericanismo histórico e, recentemente, setores da esquerda vêm assimilando esse antiamericanismo bolivariano como uma possibilidade para afirmar uma perspectiva política que acreditam anti-imperialista, muito embora o sentido de imperialismo seja distinto entre marxistas e bolivarianos ${ }^{12}$. Os estrategistas estadunidenses, por seu turno, historicamente têm uma crítica dura ao bolivarianismo desde que Simon Bolívar explicitou sua posição contra a Doutrina Monroe (1823) e à pretensão hegemônica de uma "América para os americanos" (do Norte). Embora não sendo tradição no debate político interno brasileiro reivindicar o bolivarianismo, o fato é

\footnotetext{
11 A ascensão do novo bolivarianismo, com Hugo Chavez Frías e a nova constituição do Estado, reinventou o país como República Bolivariana da Venezuela e não mais simplesmente Venezuela.

${ }^{12}$ Registre-se que a tradição marxista não tem a aproximação com a figura de Simón Bolívar que hoje se reivindica. Embora Simon Bolívar tenha se comprometido com os revolucionários haitianos de libertar os escravos negros, sua luta não seria bem-sucedida junto aos setores oligárquicos dos diversos países em que protagonizou a luta pela independência, que o impediram de cumprir aquele seu compromisso. É interessante perceber que os pensadores tradicionais de esquerda não devotem maior apreço a José Artigas (1764-1850), que explicitamente colocara a questão da libertação dos negros e indígenas e da reforma agrária desde os primeiros momentos da independência.
} 
que alguns intelectuais com forte influência nos meios de comunicação vêm fazendo recentemente uso dessa expressão e não raro ouvimos discursos contra a ditadura chavista e bolivariana e críticas à política externa recentemente posta em prática no país, sobretudo após 2003, com a posse de Lula da Silva. Desde então, se pôs em curso uma política que retoma o projeto de um Brasil Potência, agora em torno dos BRICS, de uma integração Sul-Sul com ênfase na integração latino-americana com a UNASUL - União das Nações Sul Americanas - e na CELAC - Comunidade de Estados Latino-Americanos e Caribenhos, com o COSIPLAN/IIRSA, entre outras iniciativas, que também incluem maior aproximação com a África.

Assim, vemos na América Latina hoje a atualização de um conflito histórico que atravessa o continente desde 1823, com a Doutrina Monroe, e desde 1826 com a denúncia de Simon Bolívar no Congresso Anfictiônico, realizado no Panamá ${ }^{13}$. De certa forma, os intelectuais e a grande mídia que hoje no Brasil vêm fazendo a crítica a essa política, ao adotarem o bolivarianismo como tema de polarização nos ajudam a entender o novo contexto geopolítico global em que os gestores estatais passam a desempenhar um papel mais ativo, sobretudo com a ascensão da China e o deslocamento para o Pacífico do centro geográfico da produção industrial mundial.

$\mathrm{Na}$ verdade, pode-se dizer que esse conflito se inicia quando os EUA se colocam contra a independência da Haiti apoiando a França contra os "jacobinos negros" (JAMES, 2000 [1938]). Nesse caso, não se colocam como americanos, mas sim apoiadores de uma potência colonial diante da iminência da libertação do Haiti. Essa clivagem histórica com/contra os EUA é atualizada pela "revolução bolivariana" posta em curso na Venezuela desde a posse de Hugo Chávez Frías, em 1999. Na verdade, o que Luiz Inácio Lula da Silva retoma, em 2003, é o projeto geopolítico estratégico que pelo menos desde os anos 1930 vem sendo formulado por intelectuais do campo diplomático e militar no Brasil. Àquela época, vários estrategistas justificavam uma aproximação com a Alemanha, não tanto por afinidade ideológica com o nazifascismo, como se acostuma atribuir, mas por razões geoestratégicas e num momento em que a hegemonia da Inglaterra começava a ser deslocada para os Estados Unidos. Afinal, para alguns estrategistas militares e diplomatas brasileiros, a Alemanha, por seu potencial científico-tecnológico, poderia oferecer ao Brasil condições para que as Forças Armadas pudessem exercer sua função constitucional mais legítima, qual seja, garantir a integridade territorial do Estado. Como é sabido entre os intelectuais do campo militar, a extensão territorial do país e a sua relativa baixa densidade demográfica exigem, do ponto de vista estratégico, uma inteligência que dependeria do desenvolvimento científico e tecnológico para que se possa cumprir os "objetivos nacionais permanentes". Não sem razão, os militares não só foram protagonistas na luta pela soberania energética com a campanha "O Petróleo é Nosso", que levou à criação da Petrobrás, como na

\footnotetext{
${ }^{13}$ Simon Bolívar já formulara uma visão crítica na Carta da Jamaica, escrita em 1815, que se constitui na primeira análise de conjunto do continente.
} 
criação do Conselho Nacional de Desenvolvimento Científico e Tecnológico CNPq -, em 1952. E, nesse caso, o fizeram acompanhando o novo estado da arte no que diz respeito às condições de possibilidade para o exercício da soberania dos países no pós-Hiroshima, isto é, quando avaliaram que nenhum país no mundo poderá exercer sua soberania sem o acesso à tecnologia nuclear e seus subprodutos atômicos no pós-guerra. E, por isso, o desenvolvimento científico e tecnológico deveria ser estimulado com o CNPq. É essa mesma razão que nos ajuda a entender porque o General Ernesto Geisel, presidente numa ditadura militar (1964-1985) que prendia comunistas e em plena Guerra Fria, tenha rompido unilateralmente, em 1976, o acordo militar Brasil-EUA e, de imediato, tenha estabelecido um acordo nuclear com a Alemanha para construir o complexo nuclear de Angra dos Reis. Houve, por parte dos estrategistas brasileiros à época, uma avaliação de que a demora dos estadunidenses em proporcionarinformações sobre a tecnologia nuclear, como estabelecia o tratado militar entre os dois países firmado no pós-guerra, não era um acidente, mas parte de uma estratégia de retardar o acesso do Brasil a essas informações. Relembremos que o Itamarati, muito embora fosse signatário de origem do Tratado de Tlatelolco (1967), que proíbe a presença de armas nucleares na América Latina e no Caribe, se recusara a firmar o TNP(Tratado de NãoProliferação de Armas Nucleares), de 1968. Este tratado seria assinado, mais tarde, em 1998, por $\mathrm{FHC}$, que, assim, se rendia às potências que já tinham armas nucleares. Logo depois, o mesmo FHC romperia o acordo militar Brasil-Iraque, que se desenvolvera à sombra do acordo nuclear Brasil-Alemanha, o qual conformara um tripé de colaboração tecnológica nuclear entre Brasil, Alemanha e Iraque. Como se viu nos anos 1970, os estrategistas militares retomaram uma política de Estado que procurava se desvincular de uma dependência geopolítica dos EUA, o que nos mostra que há uma tensão/disputa interna ao campo da formulação das políticas estratégicas: de um lado, uma posição que, embora não seja antiamericana, reconhece que há uma tensão geopolítica com os EUA, como se pode ver com a denúncia do acordo militar com esse país (1976) e por meioda aproximação com o Iraque e com a Alemanha e, de outro lado, uma posição pró-estadunidense, como se viu no governo FHC com o rompimento do acordo militar com o Iraque e na assinatura do TNP por parte de $\mathrm{FHC}^{14}$. Todavia, essa tensão permanecerá entre os estrategistas militares e diplomatas brasileiros, como se mostrará quando o próprio FHC se recusara a coonestar o golpe de estado contra Hugo Chávez Frías, em 2002, golpe esse que fora apoiado pelos EUA, como se viu em manifestações de autoridades estadunidenses em prol do golpe. Registre-se que, desde os inícios dos anos 2000, os EUA redesenham sua estratégia militar para as Américas, logo depois da devolução do canal de Panamá aos panamenhos, quando buscam compensar essa

\footnotetext{
14 É claro que essas posições não são antagônicas. Podem se aproximar quando, eventualmente, identificam um inimigo comum que bem pode ser a "república sindicalista" ou "perigo comunista", como parece ter sido o caso no golpe militar de 1964.
} 
perda aumentando sua presença na região andino-amazônica através do Plano Colômbia a pretexto de combater o narcotráfico. Ainda no final do ano de 2002, FHC já em final de mandato e derrotado nas urnas, age de modo ativo em apoio a Hugo Chávez Frías, enviando um navio-tanque com gasolina para abastecer Caracas num momento em que os grupos empresariais daquele país, com o apoio dos EUA, faziam um blecaute com sonegação de combustível, paralisando a capital do país com o claro objetivo de gerar uma comoção popular contra o governo democraticamente eleito no país vizinho ${ }^{15}$. Consideremos, ainda, (1) que a Venezuela é o maior país exportador de petróleo para os EUA e que continuou a sêlo mesmo nos sucessivos governos bolivarianos sob a liderança do chavismo e (2) que o protagonismo desse país à frente da OPEP conseguira colocar os preços do barril de petróleo na faixa de US\$100. A Venezuela viria se tornar, ao longo dos anos 2000, o principal parceiro comercial do Brasil entre os países da América Latina, superando, inclusive, a Argentina e o México, países com economias mais fortes do que a da pátria de Bolívar. Para os grupos/classes sociais que mantêm a tradição antiamericana na Venezuela, o Brasil é um parceiro privilegiado em sua busca de superação da influência estadunidense e, assim, se fortaleceram os laços entre os dois países desde os anos 2000. Registremos que FHC e Hugo Chávez Frías já haviam inaugurado o "tendido eléctrico" que transmite energia da maior hidrelétrica venezuelana, El Guri, no rio Orenoco, até Boa Vista, em Roraima. Portanto, a aproximação Brasil-Venezuela parece escapar do reducionismo ideológico com que o tema das relações internacionais vem sendo tratado, sobretudo na atual crise. E mostra que há uma disputa sobre os diferentes caminhos da política externa brasileira, para além do maniqueísmo ideológico da guerra fria que continua sendo acionado à direita e à esquerda.

\section{O fator China e as novas tensões territoriais em curso}

Desde 1974 o Brasil estabelece relações diplomáticas com a República Popular da China, logo depois de Nixon-Kissinger visitar a China e estabelecer uma aliança antissoviética. Em $1988^{16}$, Brasil e China firmam o Programa Espacial SinoBrasileiro,

uma iniciativa pioneira e sem paralelo, tanto na cooperação SulSul, como Norte-Sul. A parceria para o desenvolvimento e lançamento dos satélites CBERS (China-Brazil Earth Resources

\footnotetext{
15 Nesse caso, parece que a defesa da soberania nacional estaria sendo ameaçada pela presença estadunidense nas cercanias da Amazônia.

${ }^{16}$ Desde os anos 1980 que os estrategistas militares brasileiros mudaram a "hipótese de guerra", que deixou de ser uma guerra na Bacia do Prata contra a Argentina, uma herança do período colonial. Desde então, a nova "hipótese de guerra" passou a ser a ameaça que paira sobre a Amazônia.
} 
Satellite) permitiu ao Brasil entrar para o seleto grupo de países detentores da tecnologia de geração de dados primários de sensoriamento remoto para os estrategistas brasileiros, possibilitando uma ferramenta estratégica para monitorar seu vasto território (MORENO, 2015, p. 48).

Desde então, os dois países têm assumido posições identificadas com o multilateralismo e, nesse sentido, o Brasil se apresenta com posições que não se alinham automaticamente com os EUA que, desde a queda da URSS, vem assumindo uma política cada vez mais unilateral. A Venezuela, assim como o Brasil, estreitará suas relações com a China e, por seu bolivarianismo histórico, verá nisso uma oportunidade de afirmar seu antiamericanismo. O fator China, nesse sentido, virá contribuir para a afirmação e atualização do bolivarianismo e, como não poderia deixar de ser, contraditoriamente de sua face antibolivariana. Em suma, vimos que já em finais da década de 1990 havia uma aproximação do Brasil com a Venezuela, quando FHC inaugurara junto com Hugo Chávez Frías a linha de transmissão entre El Guri e Boa Vista. No ano 2000, o mesmo FHC propõe um grande projeto de integração física da América do Sul, a IIRSA - Iniciativa de Integração Regional Sul Americana - e, observe-se, não é a América Latina que está sendo invocada, mas sim América do Sul. Sabemos que a expressão América Latina tem um forte componente de antagonismo com/contra a América Anglo-Saxônica, com/contra os EUA em particular, pelo menos entre alguns setores das elites criollas. Observemos, de passagem, que a IIRSA é proposta no mesmo momento em que o presidente neoliberal mexicano Vicente Fox propõe outro grande projeto de integração física chamado à época PPP (Plan Puebla-Panamá, na América Central), com os mesmos pressupostos teórico-políticos da IIRSA. E, destaquemos, os dois projetos contavam com o apoio de instituições multilaterais, como o BID e o BIRD. Na verdade, estes projetos de integração física nos remetem ao que o geógrafo Milton Santos ${ }^{17}$ houvera chamado de "sistema de objetos" (estradas, portos, aeroportos, hidrovias, ferrovias, hidrelétricas, pontes), que complementava o "sistema de normas", o qual, no caso, vinha sendo proposto como ALCA - Aliança de Livre Comércio das Américas. Através da ALCA, o que se objetivava era o interamericanismo, que, na diplomacia estadunidense, se configura como uma ideia-chave,a qual não faz distinções entre a América - seja do Norte, Central ou do Sul - e, menos ainda, entre América Anglo-Saxônica e América Latina, distinção ainda mais acentuada por intelectuais antiamericanos históricos, como José Martí,com sua designação de Nuestra América. Após a eleição (1998) e posse (1999) de Hugo Chávez Frías, o projeto da ALCA começa a ser questionado, até ser abandonado em 2005, já com o apoio do Brasil de Lula da Silva, que adotara o projeto diplomático-

\footnotetext{
${ }^{17}$ Para Milton Santos, o espaço geográfico é um híbrido constituído por um "sistema de objeto" e um "sistema de ações". No caso em questão, a IIRSA e a ALCA.
} 
militar de não alinhamento automático com os EUA que, como vimos, já vem se delineando desde os anos 1930. E mais, desde 2003 essa política ganha apoio financeiro pesado via BNDES, quando Lula da Silva assina um decreto que permite que esse grande banco de fomento empreste capital para empresas brasileiras fora do Brasil, o que não era permitido desde sua fundação, em 1952. E o BNDES, registrese, é o maior banco de fomento do mundo fora da China, com cerca de US\$ 100 bilhões para investimentos anuais. Enfim, pela primeira vez se pode dizer que as condições materiais de possibilidade de uma política de não alinhamento automático aos EUA começaram a se desenhar concretamente, para o que a China e o Brasil tiveram um papel decisivo nesse sentido. Afinal, sem esse peso geopolítico do Brasil e da China, o bolivarianismo propriamente venezuelano não passaria, mais uma vez, de mera retórica.

A geografia, nessa nova quadra de reorganização espacial do capitalismo, falará ainda mais alto para a América, sobretudo para sua sub-região América do Sul. Afinal, o Brasil, país com maior extensão geográfica, maior população e maior economia da América depois dos EUA, sempre esteve voltado para o Atlântico, e, agora se vê instado a uma grande manobra geopolítica, ao ter que se voltar para o Oceano Pacífico e para a Ásia. A envergadura de capitais necessários para isso implica obrigatoriamente um protagonismo além do capital privado, ainda que o faça em aliança com o capital. Afinal, não é só o capital que opera como agente geopolítico, mas, sobretudo o Estado, que detém a prerrogativa de ordenador territorial que, no fundo, é quem pode apresentar razões de interesse geral (raison d'État) ou de interesse nacional, ou o que mais o valha. Nenhum capital isoladamente pode, enquanto tal, fazer essa função, a não ser quando algum Estado lhe empreste essa função. A lógica do capital e a lógica territorialista, mesmo não sendo antagônicas, são diferentes.

E como parte desta manobra geopolítica com vistas a integrar-se aos mercados asiáticos, a China se apresentou como um parceiro ideal para afirmar o novo bloco político que se forjara em torno de governos que se apresentam como pósneoliberais que, não olvidemos, foram possíveis em função das grandes mobilizações contra o neoliberalismo ao longo da década de 1990, período em que as esquerdas tradicionais perderam muito de seu protagonismo. Assim, as estruturas físicas de integração que foram propostas com a IIRSA para viabilizar a ALCA acabaram por servir a uma integração física do subcontinente com o novo centro industrial do mundo capitalista, que se desloca para a China. O crescimento exponencial da China, de mais de dois dígitos durante mais de duas décadas, garantiria a demanda de commoditties de grãos, carnes, madeiras, minérios, petróleo e gás, que alavancaria a acumulação de capitais, sobretudo dos grandes capitais, que, por sua magnitude, podiam se apresentar para operar nessa escala geográfica globalizada e atender aos volumes demandados pela China. Portanto, a abertura de 
novas condições logísticas nos fronts de expansão/invasão ${ }^{18}$ de capitais (estradas, portos, aeroportos, hidrelétricas, concessões de áreas do subsolo para explorar minérios, gás e petróleo) não beneficiaria igualmente os diversos capitais, nem tampouco os diferentes grupos/classes sociais, menos ainda aqueles em situação de subalternização. As escalas geográficas nunca são neutras social, cultural e politicamente. Assim, a expansão geográfica do capital tende a fortalecer a concentração e a centralização de capital e, desse modo, amplia a injustiça e a concentração de poder que a sustenta. E nessas frentes, ou melhor, nesses verdadeiros fronts de expansão/invasão do processo civilizatório comandados pelos gestores e pelos capitalistas, há muita barbárie. Para isso, não faltaram ideólogos para justificar e fundamentar políticas de ajuste aos novos ditames geopolíticos, como se pode notar na declaração do Secretário da UNASUL, o venezuelano Alí Rodríguez Araque, em 2012, explicitando e atualizando a continuidade histórica dessa função colonial de nosso continente:

Eu não tenho dúvida em afirmar que, precisamente, se a maior fortaleza de que dispomos, é essa gigantesca reserva de recursos naturais, essa é a fortaleza que devemos aproveitar para combater a pobreza, para gerar emprego que, por sua vez, expande o mercado interno, que cria o primeiro passo para combater a pobreza que gera, em consequência, um conjunto de resultados positivos para toda a região. Então, se trata de traçar una estratégia que tenha como grande objetivo o óptimo aproveitamento desses recursos naturais, com vários objetivos. Desde logo está a necessidade de obter renda para os estados, e para isso inclusive, é necessário tomar em conta outro fator, todo recurso natural está alojado na terra, e ao estar na terra sua exploração comporta ocupação territorial, e isso leva a colocar o problema da soberania ${ }^{19}$.

Assim, a China viria a tornar-se, já em 2009, o principal parceiro comercial da América Latina. A estratégia política que vem sendo desencadeada pelo Estado chinês, sob coordenação do Partido Comunista, busca garantir o suprimento de alimentos e matérias-primas para o parque industrial do capital transnacionalizado que opera na China. Enfim, uma aliança inimaginável para os paradigmas analíticos convencionais se forja entre (1) as grandes corporações capitalistas industriais e financeiras mundiais, (2) os gestores do Partido Comunista chinês, (3) o capital

\footnotetext{
${ }^{18}$ Front é o conceito militar que designa um espaço em disputa. Resolvida a disputa, o front se transforma em fronteira e, geralmente, os diplomatas são chamados a escolher um rio ou outro acidente geográfico natural para apagar o caráter político-militar do front, como se a fronteira fosse natural. Ou então, a recorrer às matemáticas da cartografia com as suas latitudes e longitudes para emprestar cientificidade e neutralidade ao que não é fruto nem da ciência, nem da neutralidade, mas sim da política.

${ }^{19}$ Consultar http://www.unasursg.org/uploads/77/cd/77cd2a99a9fd1432bc75b0070fb43b08/Discurso-AliRodriguez-Posesion-Secretaria-General.pdf. Acesso feito em 12/02/2014.
} 
financeiro brasileiro, com grande participação dos fundos de pensão brasileiros ${ }^{20}$, (4) as grandes oligarquias latifundiárias moderno-coloniais brasileiras e (5) setores dos gestores militares e diplomatas de carreira no Estado brasileiro.

Os estrategistas das grandes corporações brasileiras explicitam essa aliança e antagonismo, para eles só aparente, de sua ação em relação à política externa estadunidense. É o que se lê nesta análise de um dos intelectuais ligados à construtora Andrade Gutiérrez.

En cierto sentido, se podría decir que en su discurso básico, el gobierno Lula retomó, aparentemente todavía con más énfasis, parte de la visión regional del gobierno Fernando Henrique Cardoso, a cuya iniciativa se debe la realización de la primera cumbre de los países de América del Sur. (...) A pesar de eventuales diferencias de medios y estilos, hay, pues, una cierta continuidad en el sentido del establecimiento, en el continente, de un nuevo regionalismo, el "suramericanismo", distinto tanto de la noción monroista de panamericanismo cuanto del "latinoamericanismo" tradicional de remota inspiración bolivariana. Este nuevo regionalismo definiría mejor los tipos de actuación adecuados a cada región pero no excluiría, más bien reforzaría, los lazos con otros países de América". (...) "La orientación actual trataría de, sin choques o conflictos con la "hiperpotência" septentrional, superar el panamericanismo absorbente, que tendría, por la dinámica de fuerzas en acción, a llevar de manera más o menos formal todos los países del continente a la órbita de Washington. Por otro lado, según nuestro actual Ministro de las Relaciones Exteriores Celso Amorim, habría la intención de desarrollar con Estados Unidos una relación madura, de carácter más estratégica, en la cual nuestro país sería considerado como "socio indispensable para la estabilidad de América del Sur e incluso de África ${ }^{21}$ (ANDRADE GUTIERREZ, 2007).

Tudo parece indicar que o conceito de imperialismo necessita ser atualizado e talvez esteja na hora de levar a sério a advertência feita por Atílio Borón de fazer uma leitura ativa de Lênin e sua teoria sobre o tema, e não repetir passivamente o que disse o intelectual revolucionário russo. Rui Mauro Marini colocara no debate o conceito de subimperialismo para entender a posição de "cooperação antagônica" do Brasil com os EUA. Hoje, esse subimperialismo adquire sentido prático,como revela a ação de resistência de vários grupos/classes sociais em situação de

\footnotetext{
${ }^{20}$ Os maiores fundos de pensão brasileiros vêm sendo dirigidos por sindicalistas ligados à CUT e ao PT.

21 Andrade Gutierrez - Documento América del Sur: el desafio de la infraestrutura. Revista DEP Diplomacia, Estratégia y Política, 2007: 252.
} 
subalternização contra a presença de empresas brasileiras que operam na construção de estradas, hidrelétricas, portos e aeroportos, ou através da exploração mineral e agrícola com o agribusiness, em vários países da América do Sul. Um brado novo se ouve nas terras baixas da Bolívia, no conflito do TIPNIS; em Madre de Dios, no Peru; ou na Colômbia, na Venezuela, na Argentina ou no Equador, e não é mais somente o brado de "yankees, go home", mas também contra empresas brasileiras e chinesas, além das tradicionais estadunidenses, canadenses, inglesas, espanholas e australianas. E mais, os grupos/classes sociais que bradam esses slogans contra empresas brasileiras nos demais países da América Latina/AbyaYala são as mesmas forças que no Brasilse manifestam em Belo Monte, no Pará, em Jirau e Santo Antônio, em Rondônia, na fronteira com a Bolívia, ou no Porto do Açu, no Rio de Janeiro, ou contra a Cia Vale do Rio Doce/Samarco/BH Billiton, em Mariana, Minas Gerais.

Deste modo, com o aval do Estado governado por forças políticas que se apresentam como pós-neoliberais em aliança com os capitais da China sob o comando do PC chinês, estradas, portos, aeroportos, ferrovias e hidrovias passam a abrir os caminhos para o trânsito de grãos, carnes, madeiras, minerais, petróleo e gás cuja produção aumenta pela maior oferta de energia com grandes hidrelétricas, sobretudo na Amazônia. A legislação de acesso à terra e ao subsolo, assim como a legislação ambiental, foi adequada aos interesses dosgrandes capitais do agronegócio (Friboi, Sadia, Cargill, Bunge etc.), das grandes empresas de engenharia e construção civil (Odebrecht, OAS, Camargo Correia) para construir portos, pontes, aeroportos, estradas, hidrelétricas e hidrovias e para as empresas mineradoras e de petróleo (Vale, Petrobrás, 20 etc.), contra os interesses dos camponeses, quilombolas e indígenas com generalizada regressão da legislação ambiental e dos direitos dos quilombolas e indígenas, como se vê no desprezo pelo Convênio 169 da OIT, a última grande conquista de direitos em escala mundial feita por grupos/classes sociais em situação de subalternização, ainda antes da regressão de direitos que promoveria o neoliberalismo após 1989.

Os volumes e escala em que operam esses grandes capitais impõem uma velocidade que tornam atrasados/indolentes e preguiçosos todos os que não são de seu tempo, de sua velocidade. Não se ignore que chamar alguém de atrasado ou adiantado só tem sentido se o colocamos previamente diante da mesma linha evolutiva, logo, não se admite o outro, a diferença. Por isso, a racionalidade gestorial invoca o interesse geral, o interesse nacional, e ignora as múltiplas territorialidades que fazem parte do mesmo Estado territorial ${ }^{22}$. O novo ordenamento

\footnotetext{
${ }^{22}$ Seria interessante, a respeito dessas questões, verificar a resposta de Karl Marx à carta da revolucionária russa Vera Zasulich, que lhe indaga sobre o que fazer com relação às tradicionais comunidades camponesas russas, a obschina. Marx afirmara que se aquelas comunidades viessem a acabar não seria por nenhuma lei histórica de estágios necessários do dever histórico. Contra esse evolucionismo, Marx afirmara que ali estavam presentes valores e práticas mais próximas do comunismo e que os
} 
territorial se mostra, ao mesmo tempo, como desordenamento territorial. A colonialidade aparece como condição necessária da modernização, da modernidade! A violência contra a natureza e os grupos/classes sociais em situação de subalternização se mostra aguda, como demonstram o aumento do número de conflitos e a devastação das condições materiais da vida, com a poluição das águas, a diminuição da piscosidade a jusante das barragens hidrelétricas, a poluição do ar, a erosão dos solos e a dilapidação do subsolo e, ainda, na vida precária nos alojamentos das construções, nas periferias urbanas, com a drogadição, a prostituição e outras formas degradadas da vida, como a delinquência juvenil e a maternidade precoce.

No conflito contra o governo boliviano de Evo Morales em 2009/2010, protagonizado pelo complexo da República da Soja - como se autodenominam as oligarquias latifundiárias moderno-coloniais aliadas do capital financeiro da Cargill, Monsanto e outras grandes corporações com sede nos países centrais do capitalismo mundial (Figura 2) - e, ainda, pela tecnoburocracia gestorial (como a Embrapa, no Brasil) se chegou ao cúmulo de propor a separação das Terras Baixas bolivianas, que chamaram de Media Luna (Santa Cruz de La Sierra, Beni, Pando e Tarija), mas encontraram a firme determinação da UNASUL contra tal separação. Todavia, logo a seguir, o governo brasileiro ofereceria ao governo boliviano de Evo Morales financiamento para a construção de uma estrada que atravessaria a Terra Indígena do Parque Nacional (dos rios) Isiboro-Secure - TIPNIS -, contra os povos indígenas que ali habitam ancestralmente e que tiveram um papel fundamental na conformação da nova agenda teórico-política que veio a se implantar no país quando, em 1990, fizeram a I Grande Marcha pela Vida, pela Dignidade e pelo Território. Em 2010, essas mesmas forças organizaram a VIII Marcha, que reiterava as mesmas reivindicações da Marcha de 1990, e se transformaria na maior manifestação da história da Bolívia, com cerca de 500 mil pessoas em La Paz. Além disso, chama atenção que o atual governo boliviano tenha chamado para si a responsabilidade de, enfim, realizar a integração nacional do país, interligando todas as capitais departamentais, olvidando que a Bolívia não é mais um Estado nacional, mas sim plurinacional e, mais, comunitário, como reza a nova constituição do Estado. Desse modo, não caberia mais falar de integração nacional, mas sim de integração plurinacional (PORTO-GONÇALVES \& BETANCOURT, 2016) ${ }^{23}$.

revolucionários russos deveriam lutar contra o capitalismo, inclusive para preservar aquelas comunidades tradicionais (MARX, 1990).

${ }^{23} \mathrm{O}$ mesmo se pode notar no Equador, onde o governo da "Revolução Cidadã", comanda por Rafael Correa, ratificara, em 2008, o papel estratégico do IAEN - Instituto de Altos Estudos Nacionais - sem sequer respeitar o fato da nova constituição do Estado ter jurado respeitar, redefinir o Estado equatoriano, não mais como Estado nacional, mas sim como Estado Plurinacional 


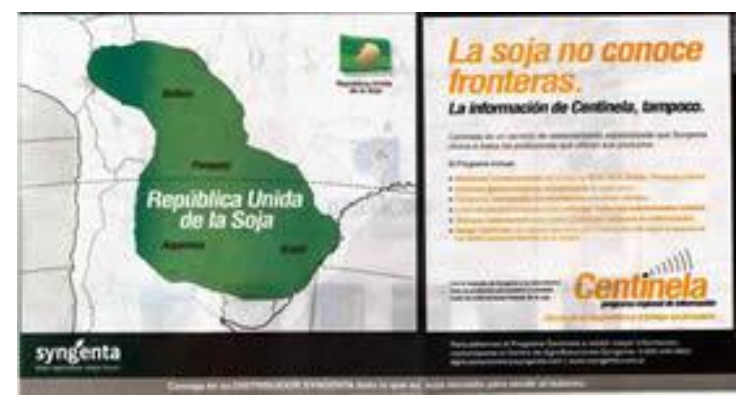

Figura 2: A República da Soja ${ }^{24}$.

Diante da atual crise, se pode notar um novo consenso não mais de Washington, mas de Beijing, ou melhor, o "consenso das commoditties" como bem chamou Maristela Svampa (2013). A mesma infraestrutura física proposta pela IIRSA que serviria à ALCA vem servindo à integração do novo centro geográfico do capital industrial na Ásia, sobretudo na China. Ou melhor, essa estrutura física foi ampliada ao porto de Mariel, em Cuba, ao novo canal que liga o Pacífico ao mar do Caribe, na Nicarágua, sob controle de capitais chineses, o que, sem dúvida, obrigou o governo estadunidense a rever sua política de bloqueio a Cuba e ensejou as condições para que o governo da Colômbia tomasse a iniciativa de propor um acordo de Paz à guerrilha para poder promover a exploração da bacia do Orenoco e da Amazônia. $\mathrm{Na}$ Venezuela, o Arco Mineiro do Orenoco proposto pelo governo bolivariano abre amplas áreas do país à expansão dos capitais de exploração de empresas de mineração tradicionais agora em companhiasde capitais chineses e russas e, assim, extensas áreas do país estão oferecidas ao avanço dos capitais com toda a violência que costuma acompanhar esses processos, como vêm assinalando os movimentos sociais. E, contra estes gestores nacionalistas que privilegiam as dinâmicas territoriais dos Estados e sua geopolítica que vem dando suporte aos grandes grupos empresariais do agribusiness e da exploração mineral, gritam as territorialidades dos grupos/classes sociais em situação de subalternização que estão sinalizando que a violência que vêm sofrendo tem as marcas do latifúndio e do grande capital, que caminham de mãos dadas, usando tecnologias de ponta que produzem carnes de frango, de porco ou de gado ou os grãos de soja (pasta para o gado, óleo vegetal biodiesel), milho, soja e cana,como alimento e como energia, ou seja, em produtosflex. Enfim, mais da modernização conservadora que nos governa há 500 anos! Afinal, desde os inícios do século XVI, pelo menos no Brasil, Cuba e Santo

\footnotetext{
${ }^{24}$ Em 2003, a transnacional Syngenta publicou no Clarín e La Nación, dois dos mais importantes jornais argentinos, um informe publicitário sob o título de República Unida da Soja. A imagem acima desse informe publicitário de caráter colonial foi obtida em 18-02-2014, no link http://www.grain.org/es/article/entries/4739-larepublica-unida-de-la-soja-recargada.
} 
Domingo (Haiti) que se planta cana em grandes latifúndios para exportar não a matéria-prima cana, mas sim açúcar, produto industrializado em engenhos, tecnologia de ponta que à época não encontrava paralelo em seu nível de desenvolvimento na Europa. A modernidade tecnológica subordinada à acumulação de capital surge na colônia junto com o latifúndio e suas monoculturas de exportação e com a superexploração do trabalho e o racismo. Talvez a mais significativa mudança dessa moderno-colonialidade desde essa época seja a magnitude de transformação metabólica alcançada pelo nível de desenvolvimento das forças produtivas, sobretudo depois que substituiu o Sol nosso de cada dia (fotossíntese) pelo Sol de ontem, cuja fotossíntese está no fóssil do petróleo e do gás. Talvez seja o caso de chamarmos de forças disruptivas, pelo colapso metabólico cujos sinais já começamos a ver com adesordem climática global, com erosão de solos, com a perda de diversidade biológica, a contaminação das águas e a violência contra povos/etnias/nacionalidades (epistemicídio/etnocídio). Como essa dinâmica metabólica está subordinada a uma acumulação de capitais que se quer sem limites, será a natureza e serão os grupos/classes sociais com outros valores que haverão de apontar caminhos/limites. E quando dizemos que o capital se quer sem limites, é importante resgatar que limite, em grego, polis, era o muro que separava a cidade do campo. Depois, passou-se a chamar polis ao que estava entre os muros, a cidade, onde se debatiam os limites, ou seja, se fazia política ${ }^{25}$. Ouçamos, pois, o que nos dizem os povos em sua luta pela vida, pela dignidade e pelo território, que estão nos oferecendo outro léxico teórico-político em que o Estado não seja somente nacional, mas plurinacional; que o Estado reconheça que dentro de um mesmo território habitam múltiplas territorialidades; onde mais que luta pela terra, que se lute pela terra como território; que não busquemos mais alternativa de desenvolvimento, mas alternativas ao desenvolvimento ${ }^{26}$; onde a natureza seja portadora de direitos, como consagram as novas Cartas Magnas da Bolívia e do Equador.

A atual crise brasileira, que mais uma vez se inscreve na crise latino-americana, talvez tenha, na atual quadra histórica, a virtude de nos mostrar o quanto nosso destino está ligado aos demais povos do continente. Há um grito que vem da América Profunda/AbyaYala, que há mais de 500 anos luta contra o colonialismo e a colonialidade que o atualiza, e que nos convoca a ver que a luta contra o capitalismo implica também a luta contra a colonialidade que lhe é constitutiva. Afinal, a acumulação primitiva é a face violenta da acumulação civilizada que a põe e pressupõe.

Quando sugerimos que devemos ouvir esse grito, queremos chamar a atenção para o movimento que fazemos quando queremos escutar uma voz que se apresenta a princípio inaudível. Geralmente,para ouvir essa voz colocamos a mão por detrás

\footnotetext{
25 Não olvidemos, pois, que limite é a essência da política, e haveremos que reinventá-la contra a Oligarquia - para os gregos, governo de poucos, e a Tirania, governo de Um.

26 Vida em Plenitude, Buen Vivir, SumakKawsay, Sumaq Qamaña, Ubuntu são alguns nomes que procuram indicar outros horizontes de sentido para a vida para além do desenvolvimento.
} 
do ouvido e nos movemos em direção ao outro, aproximando-nos. Esse movimento é diferente daquele que privilegia a visão,que quer ver de longe, com um olhar de sobrevoo dos "homens de visão",o qual, geralmente, implica um movimento de afastamento. Ouçamo-la, aproximando-nos. Quem sabe, assim, a razão se beneficie do sentimento e pense com a dor dos que gritam.

\section{Bibliografia}

ABENSOUR, Miguel. (1998) A Democracia contra o Estado - Marx e o momento maquiaveliano.Belo Horizonte: Ed.UFMG.

ANDRADE GUTIERREZ. (2007) América del Sur: el desafio de la infraestrutura. Revista DEP - Diplomacia, Estratégia y Política. p. 252.

ALIMONDA, Hector. (Org.) (2002) Introducción: política, utopía y naturaleza. In Ecología Política - Naturaleza, sociedad y utopía.Buenos Aires: Clacso. pp. 7-14.

ALTVATER, Elmar. (1994) O Preço da Riqueza. São Paulo: Edunesp.

ANDERSON, Perry. (1984) Linhagens do Estado Absolutista. Porto: Afrontamento. ARENDT, Hanna.(1995)A Condição Humana. Rio de Janeiro: Forense Universitária.

. (1971) Sobre a Revolução. Lisboa: Moraes Ed.

ARRIGHI, Giovanni. (1994) O Longo Século XX. São Paulo: Contraponto/Unesp. BERNARDO, João. (1991) Economia dos Conflitos Sociais. São Paulo: Cortez ed. BORÓN, Atílio. (2006) Marxismo Hoje. São Paulo/Buenos Aires: Clacso. . (2002) Império - Imperialismo: uma leitura crítica de Michael Hardt e Antonio Negri. Buenos Aires: Clacso.

CAYCEDO, Jaime. (2004) Impacto Regional del Conflicto Colombiano en América Latina. In: CECEÑA, Ana Esther (Org.). Hegemonías y Emancipaciones en el Siglo XXI. Buenos Aires: Clacso. pp. 59-71

CASTORIADIS, Cornelius. (1982) A Instituição Imaginária da Sociedade. Rio de Janeiro: Paz e Terra.

CECEÑA, Ana Esther \& BARREDA Andrés. (Coord.) (1995) Producción estratégica y hegemonía mundial. México: Siglo XXI.

. (2002a) A Guerra Infinita - hegemonía e terror mundial. Rio de Janeiro:

Vozes/LPP/Clacso.

. (2001) La Territorialidad de la dominación. Estados Unidos y América Latina. Revista Chiapas, no 12, 7-30. México: UNAM/Ediciones Era.

CLASTRES, Pierre. (1982) Arqueologia da Violência - Ensaios de Antropologia Política. São Paulo: Brasiliense.

- (2003) A Sociedade contra o Estado - Pesquisas de Antropologia Política. São Paulo: Cosac Naify. 
CUSICANQUI, Silvia Rivera (1990) El potencial epistemológico y teórico de la historia oral: de la lógica instrumental a la descolonización de la historia. Temas Sociales, $\mathrm{n}^{\circ} 11$, La Paz.

DÁVALOS, Pablo (2000) Ecuador: las transformaciones políticas del movimiento indígena ecuatoriano. Boletin do ICCI, $\mathrm{n}^{\circ} 11$, ano 2, fevereiro.

.(2004) El Discurso de La Modernidad: Poder y violência em La Amazonía Ecuatoriana.Trabalho apresentado na Reunião do GT Ecologia Política de Clacso - outubro de 2004. São Paulo. Mimeo.

DAVIS, Mike. (2006) Planeta Favela. São Paulo: Boitempo.

DIEGUES, Antonio Carlos. (1996) O Mito Moderno da Natureza Intocada. São Paulo: Hucitec.

DUSSEL, Enrique. (2000) Europa, Modernidad y eurocentrismo. In: LANDER, Edgardo (Org.) La Colonialidad del Saber - eurocentrismo y ciencias sociales perspectivas latino-americanas. Buenos Aires: Clacso/Unesco.

ESCOBAR, Arturo. (1996a)La Invención del Tercer Mundo - Construcióny Desconstrución del Desarrollo. Santa Fe de Bogotá: Norma ed.

FALS BORDA, O. (Org.). (1998)Participación popular: retos del futuro. Bogotá:ICFES/IEPRI/COLCIENCIAS.

GARCIA LINERA, Álvaro. (2001) Multitud y Comunidad - La Insurgencia Social en Bolivia en Bolivia. Revista Chiapas, n 11, 7-16. México: UNAM/Ediciones Era. (2003) Democracia liberal vs. Democracia comunitaria. El Juguete Rabioso, 79, de 11 a 24 de mayo.

GONZALEZ CASANOVA, Pablo. (2006) O Colonialismo Interno. In: BORÓN, Atílio.Marxismo Hoje. São Paulo/Buenos Aires: Clacso.

GRAMSCI, Antonio. (1974) A Questão Meridional. Revista TEMAS. São Paulo.

GUATARRI, Felix. (1982) Micropolítica - Cartografias do Desejo. Rio de Janeiro: Brasiliense.

GUTIÉRREZ, Guillermo. (2004) Patagonia, una regiónsinrealidad? Disponível em: <http://www.eldescamisado.org/pininueva2.htm>.

HAESBAERT, Rogério. (2004) $O$ Mito da Desterritorialização: do 'fim dos territórios' à multiterritorilidade. Rio de Janeiro: Bertrand Brasil.

LAFONT, Robert. (1971) La Revolución Regionalista. Barcelona: Ed. Ariel.

LANDER, Edgardo (Org.) (2000) La Colonialidad del Saber - eurocentrismo y cienciassociales - perspectivas latino-americanas. Buenos Aires: Clacso/Unesco.

LEFF, Enrique (1994) Ecología y Capital. México: Siglo XXI.

(2005) Racionalidad Ambiental - la reapropiación social de la naturaleza. México: Siglo XXI.

LENIN, V. I. (1947) O Imperialismo, estágio superior do capitalismo. Rio de Janeiro: Ed. Vitória.

MACHADO ARAÓZ, Horacio. (2012) Naturaleza mineral. Una ecología política del colonialismo moderno. Tesis de doctorado, Universidad Nacional de Catamarca. Argentina. 
. (2013) Crisis ecológica, conflictos socioambientales y orden neocolonial. Las paradojas de NuestrAmérica en las fronteras del extractivismo. Revista Brasileira de EstudosLatino-Americanos, rebela 3, n 1. pp. 118-155.

MARIÁTEGUI, José Carlos.(1996)Sete Ensayos de Interpretación de la Realidad Peruana. Lima: Empresa Editora Amauta S.A.

MARINI, Ruy Mauro \& MILLÁN, Márgara. (2001) La Teoria Social Latinoamericana, 4 vol. México: Ed. El Caballito.

MARX, Karl. (1978) O Capital - contribuição à crítica da economia política, Vol. I. Rio de Janeiro: Civilização Brasileira.

MIGNOLO, Walter. (2003) Histórias Locais/Projetos Globais. Belo Horizonte: Ed. UFMG.

MORENO, Camila. (2015) Made In China. São Paulo: Fundação Rosa Luxemburgo.

OSLANDER, Ulrich. (2002) Espacio, Lugar y Movimientos Sociales: Hacia una espacialidad de resistencia. Scripta Nova, Revista electronica de Geografía y CienciasSociales. Disponível em: <www.ub.es/geocrit/menu.htm>.

PORTO-GONÇALVES, Carlos Walter. (2000)Para Além da Crítica aos Paradigmas em Crise: Diálogo entre diferentes matrizes de racionalidade. Caracas: Anais do III Encontro Iberoamericano de Educación Ambiental.

. (2001a) Geo-grafías. Movimientos Sociales, Nuevas Territorialidades y sustentabilidad. México: Siglo XXI.

. (2001b) Meio Ambiente, Ciência e Poder: diálogo de diferentes matrizes de racionalidade, em Ambientalismo e Participação na Contemporaneidade. São Paulo: Educ/Fapesp.

. (2002a) Latifúndios Genéticos y existencia indígena. Revista Chiapas, $\mathrm{n}^{\circ}$ 14, 7-30. México: UNAM/Ediciones Era.

. (2002b) Da Geografia às Geo-grafias: um mundo em busca de novas territorialidades. In: CECEÑA, Ana Ester (Org.) A Guerra Infinita - hegemonia e terror mundial. Rio de Janeiro: Vozes/LPP/Clacso. pp. 359-391

(2003) A geograficidade do social: uma contribuição para o debate metodológico sobre estudos de conflito e movimentos sociais na América Latina. Buenos Aires: Ed. CLACSO. Disponível em: http://bibliotecavirtual.clacso.org.ar/clacso/formacionvirtual/20100724072446/17por to.pdf.

. (2004) Violência e democracia no campo brasileiro: o que nos dizem os dados da CPT. In: Conflitos no campo - Brasil 2003. Goiânia: CPT.

PORTO-GONÇALVES, Carlos Walter \&BETANCOURT, Milson.(2016) Se Habe terruño al andar. Las luchas en defensa del territorio. Encrucijada latinoamericana em Bolivia. México: Ed. Itaca e UAM - Unidad Xochimilco.

POULANTZAS, Nicos. (1977) O Estado em Crise. Rio de Janeiro: Ed. Graal. 
QUIJANO, Anibal. (2000)Colonialidad del Poder, Eurocentrismo y América Latina. In LANDER, Edgardo. (Org.) La Colonialidad del Saber - eurocentrismo y ciencias sociales - perspectivas latinoamericanas. Buenos Aires:Clacso/Unesco.

RIBEIRO, Darcy. (1986) América Latina: A Pátria Grande. Rio de Janeiro: Ed. Guanabara.

SACK, Robert David. (1986) Human Territoriality: Its Theory and HistoryCambridge: Cambridge University Press.

SADER, Eder.(1988)Quando Novos Personagens entram em Cena. Rio de Janeiro: Paz E Terra.

SANTOS, Boaventura de Sousa. (2001) Nuestra América. Para reinventar un paradigma subalterno de reconocimiento y redistribución. Revista Chiapas, $\mathrm{n}^{\circ} 11$, 31-70. México: UNAM/Ediciones Era.

. (Org.) (2003) Reconhecer para libertar: os caminhos do cosmopolitismo multicultural. Rio de Janeiro: Ed. Civilização Brasileira.

SANTOS, M. (1995) A Natureza do Espaço - técnica e tempo / razão e emoção. São Paulo: Hucitec.

SHANIN, Teodor. (1990) Marx Tardioy la Via Rusa.Marxy la Periferia del Capitalismo. Madrid: Editorial Revolución.

SVAMPA, M. (2008) Cambio de época. Movimientos sociales y poder político. Buenos Aires: Ed. Siglo XXI.

(2013) Consenso de los Commodities y lenguajes de valoración en América Latina. Revista Nueva Sociedad, 244, marzo-abril.

SVAMPA, M y SLIPAK, A.(2015) China en América Latina: del Consenso de los Commodities al Consenso de Beijing". Revista Ensambles. Argentina: UNSAMUNGS.

THOMPSON, Edward. (1983)A Miséria da Teoria. Rio de Janeiro: Zahar.

(1998) Costumes em Comum: Estudos sobre a Cultura Popular Tradicional. São Paulo: Cia das Letras.

WALSH, C. (2002) Interculturalidad, reformas constitucionales y pluralismo jurídico. Boletin ICCI-RIMAI - Publicação mensal do Instituto Científico de Culturas Indígenas. Ano 4, nº 36, marzo de 2002.

WALLERSTEIN, Immanuel. (1998) Impensar las ciencias sociales. México: Siglo XXI.

(1998) El espacio-tiempo como base del conocimiento. In: FALS BORDA, O. (Org.). Participación popular: retos del futuro. Bogotá: ICFES/IEPRI/COLCIENCIAS. pp. 47-68.

ZIBECHI, Raúl. (2014) Brasil potência - Entre a integração regional e um novo imperialismo. Rio de Janeiro: Ed. Consequência.

(2016) Territórios em Resistência - cartografia política das periferias latino-americanas. Rio de Janeiro: Ed. Consequência. 